\title{
SUSTAINABLE MANUFACTURING - THE PAST, PRESENT AND FUTURE
}

\author{
Aryaman Sharma \\ U.G. Student, Computer Engineering \\ Delhi Technological University, New Delhi, India
}

\begin{abstract}
Sustainable manufacturing has become of utmost importance during these times of strained supply chain logistics and availability as highlighted by the Covid-19 pandemic. Organizations, both privately and publicly owned have realized the positive relation of economic progress and sustainable manufacturing which have made them imbibe and implement such practices. Newer technologies, efficient processes and waste reducing methods etc. have become key in any manufacturing process. This trend will continue increasing with time for production to remain economical and regular. Almost all research on this topic has focused on a particular timeline of sustainable manufacturing. The purpose of this paper is to explore the wider timeline of events that sustainable manufacturing has gone through in order to reach this importance.
\end{abstract}

Keywords - Sustainable manufacturing, Covid-19, Economical, Economic progress., Efficient.

\section{INTRODUCTION}

The term "Sustainable Development" was first coined in the Brundtland Commission Report in 1987 titled - Our Common Future: Report of the World Commission on Environment and Development. According to the United Nations, sustainable development can be defined as "Development that meets the needs of the present without compromising the ability of future generations to meet their own needs." [1]

Companies and main players in the Supply-Demand chain are often the key entities who have to propagate and practice sustainable development goals in order for a significant change to come [2]. The Sustainable Development goals are often imbibed by the companies in their Corporate Social Responsibilities [3]. The majority of manufacturing facilities are only spectators in the global energy supply chain. They keep track of total energy use and prices connected with available sources, but they frequently ignore the controllable aspects within operations that enable consumption management that adds value to the company. This is where the concept of Sustainable Manufacturing comes into play. The United States Environmental Agency defines Sustainable Manufacturing as "the creation of manufactured products through economically-sound processes that minimize negative impacts while conserving energy and natural resources." Sustainable Manufacturing is a very important niche in the study of Sustainable Development. Especially during the COVID 19 pandemic, the role of manufacturing in providing critical supplies to various sectors such as Healthcare, Food, Energy etc. has been amplified.

For example, the Center for Disease Control (CDC) which is the national public health agency of the United States and CISA (Cybersecurity and Infrastructure Security Agency) have identified critical staff belonging to various critical sectors and published various guides and safety manuals in order to safely and effectively continue manufacturing processes with minimum exposure of the people to the virus [4]. Recognizing the importance of sustainable manufacturing processes and care for the environment, the United Nations Conference on Trade and Development which was founded in 1964 initiated a Sustainable Manufacturing and Environmental Pollution (SMEP) program that had started in 2019 and will end in 2024. Along with the UNCTAD, Foreign Commonwealth and Development Office (FCDO), Department of Environment and Geography at the University of York. Due to weak environmental regulations, poor manufacturing technologies and insufficient funding, the small industries worldwide leading to increased environmental and ecological damage. Therefore, setting up SMEP would help micro-, small- and medium sized Enterprises (MSME's) to gain technological know-how in order to prevent the environmental degradation taking place in Sub-Saharan African and South Asian countries. [5]. The SMEP scoping study will use internationally recognized exposure-response relationships (ERRs) and thresholds/guidelines for human health and environmental degradation to provide a semi-quantitative assessment of damage from key industrial activities in order to translate levels of pollution into exposure and damage. [6]

The COVID-19 situation provides an opportunity to develop a versatile and resilient manufacturing framework that will ensure the production process's economic and social sustainability in the event of any such global pandemics and emergencies in the future. Therefore, it is imperative that Manufacturers, Governments and people themselves understand the importance of this situation and act on it 
collectively and comprehensively as no single party can drive the need in for Sustainable Manufacturing by themselves.

The aim of writing this research paper is to explore the gradual shift that has taken place in the Manufacturing Sector over the years and the emerging trends that are expected to have an impact on the manufacturing practices in the foreseeable future. We will see how from practicing Unsustainable manufacturing processes to imbibing Sustainable ones, integrating lean and green, environmentally friendly techniques, the manufacturing sector has changed.

Previously, writers and researchers has discussed a specific timeline in the timeline of Sustainable Manufacturing. However, very few to no research has focused to see the complete timeline and compare how it is growing in prevalence and demand due to various ecological changes that have been going on for the past few decades such as Climate Change, shift to more sustainable methods of development etc. Therefore, there is a need to fill this void and explore the evolution of Sustainable Manufacturing through time.

Another reason for this issue to be researched further is due to the recent public outcry for environmental conservation and protection that has increased manifolds over the last few decades. In a 2014 study conducted by the Clinton Global Initiative and Microsoft, it was found that about $76 \%$ of millennials surveyed were more focused on the environment [7]. Therefore, it makes a strong business case for the manufacturers to be sensitive to the concerns of this important customer segment who would like to see the products to be environmentally concerned. With the advent of technology, Reduction, reuse, recycling and remanufacturing are connected to the environmental improvements in the production processes. The manufacturing system considers zero emits (i.e., closed loops) to be an industrial ecosystem, requiring the reuse of waste or by-products in the manufacturing system. Thus, the production of zero emissions requires pollution prevention (e.g., replacement) and waste reuse capabilities.

Flexible production also requires material flexibility, and production equipment that can accommodate changes in material flows. This in turn can help to improve sustainability while at the same time maintain competitiveness. For example, more effective, recyclable packaging can improve the sustainability of packaging.

\section{HISTORY}

Historically, the idea of sustainable manufacturing and consumption can be traced to an essay written by Thomas Malthus (1766-1834) in 1798. He was an English cleric and scholar. His essay, "An Essay on the Principle of Population", he argued that while the population of humanity would keep growing exponentially over the coming decades, the food production levels would grow arithmetically [8]. He had taken the case of the United Kingdom for this study. Although this idea was presented about two hundred years ago, this idea is very relevant even today. The philosophy of sustainability has been synonymous with dystopian rhetoric since Thomas Malthus identified rapid population growth as a harbinger of humanity's doom.

Then around 1997, John Elkington defined the term "Triple Bottom Line". This approach requires that companies must measure their social and environmental aspect in addition to their financial performance other than their profit-making activities. Such early attempts at defining and conceptualization Sustainable Manufacturing helped modern day studies and thinkers to plan for the future and create new techniques to prevent overutilization of resources [9]

Historically, it is seen that the rate of consumption of resources always increases multifold with increasing population thanks to new developments and better medical services. People nowadays have consumed resources alarmingly fast, which is definitely not sustainable, because the Earth we live in cannot regenerate the materials at that rate. In comparison, world metals manufacturing grew steeply between 1950 and 2005, oil consumption was eight times higher and natural gas consumption was 14 times higher [10]. Seeing the increased consumption of minerals and energy resources, lean manufacturing processes with minimal harm to the environment must be taken in order to ensure that the resources are efficiently and effectively used. Market leaders and investors have started to accept sustainability in recent years because of its many upside potentials.

\section{THE PRESENT STATE AND INCREASING RELEVANCE}

If we see the global energy consumption and $\mathrm{CO}_{2}$ emissions in the year 2005, it is clear that the manufacturing sector contributed most in both the above-mentioned areas, contributing about $33 \%$ and $38 \%$ respectively [11]. Many multinational organizations today are attracted towards sustainable manufacturing processes mainly due to reduced cost and lesser resource wastages [12]. Various multinational companies spanning various niches of the economy like Technology, Homeware, Cosmetic etc. have profited and made billions by shifting to more sustainable, lean and greener manufacturing processes. The general public, as stated in the introduction, also support such initiatives taken by them and therefore do not mind paying extra in order to propagate the message of sustainability [13]. One vital tendency found is the economic motivation for lowering fees and enhancing productivity. Many cases are also influenced by way of the environment and society (government incentives, sector/ customer pressure, environmental rules 
and new standards) ensuing in businesses integrating extra and more sustainability in their company method and ethics. This recollects again the three interrelated dimensions of sustainability (people, planet and profit), the 3 P's, and shows that companies are primarily transferring towards sustainability through compliance to societal adjustments and requirements [14].

For example, in the Aerospace industry, Sustainable Manufacturing has taken on a more important and significant role. Use of cutting-edge materials critically affects both reallife and natural problems. The meaning of materials science and development in Airplanes couldn't possibly be more significant. The materials used as a piece of aviation and aerospace designs and car applications are essential to its successful plan, structure and working. Materials have their effect all through the whole life cycle of airplane, beginning from the plan period of their item advancement to their finish of-life removal

Various steps can be taken in order to reduce the wastage of materials, energy and wasteful byproducts formed by production of various components of an aircraft [15].

The below provided graph gives the growth in Sustainability to various companies over the past few decades. It is clear that it has picked up pace during recent years.

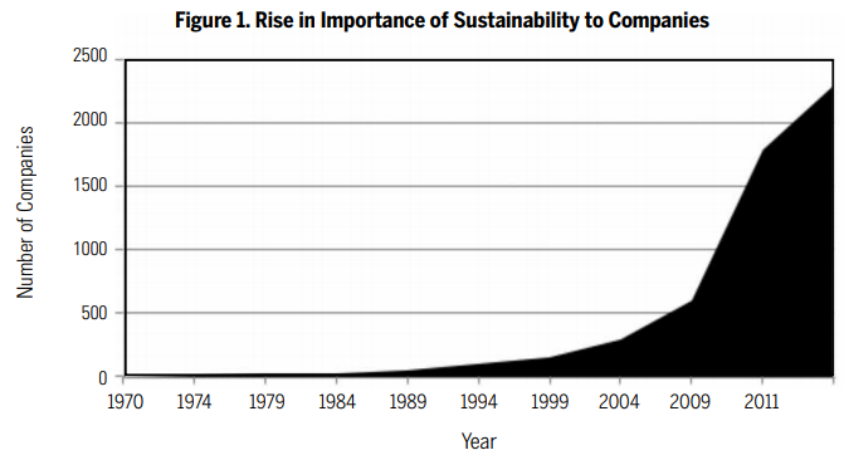

(SOURCE: Success Paths to Sustainable Manufacturing, 2014, https://oneill.indiana.edu/doc/research/sustainability2014.pdf)

\section{FUTURE OUTLOOK AND COURSE OF ACTION}

Manufacturing's past success has been built on a willingness to take chances, and the future of

industrial development will be no different. Manufacturing's past success has been built on a willingness to take chances, and the future of industrial development will be no different. The Fourth Industrial will be driven by those who invest in radical innovation and promote the adoption of lowcarbon, resource efficient technology at scale, innovative sustainable businesses and collaborative collaborations models. efficient processes and assist in the development of resilient supply chains will be in a prime position to protect themselv es against resource shortages and escalating commodity cost $\mathrm{s}$ while also collecting latent economic potential [2].

Innovative technology of today and tomorrow will make sustainable manufacturing simpler than ever before. Companies can now manufacture parts on-site rather than have them shipped from afar thanks to advances in 3D printing (or additive manufacturing). Systems and products can now interact with one another thanks to nanotechnology and the Internet of Things (IoT). This, when combined with machine learning and artificial intelligence, allows computers to automatically classify and implement the most efficient manufacturing methods. In the past, these minor but significant changes would have necessitated hundreds of hours of data analysis and calculations. They can now be finished in the blink of an eye. [16].

\section{CHALLENGES}

The traditional role of product design in manufacturing firms has been to ensure that the product achieves its desired goals based on consumer tastes, taking performance, reliability, ergonomics, and aesthetics into account. With a greater emphasis on sustainable production, the product designer now has the added burden of taking into account the environmental effects of his or her decisions. The materials and methods used have a direct impact on the final product. As a result, the designer must first familiarize himself or herself with the various issues surrounding sustainability. The environmental effect is heavily influenced by the materials and methods used [17].

Another challenge to embracing Sustainable Manufacturing is the pricing aspect of it. Due to competition, the price of the products produced must be low and at the same time must be able to produce a profit for the product to be economically viable for the company. Many industries do not want to lose out on their customers and do not ant to procure

If substantial results are to be achieved, some aspects of improving efficiency, such as changing factory layout, require time and physical space. Interviewees at the improvement sites proposed that a temporary "buffer" of time be created by using evenings or weekends, adding additional resources to the area, or temporarily increasing the number of people working in the area. Time by working evenings and weekends, committing additional resources to the field, or temporarily growing stock to 'make room' for improvement activities without affecting production requisites [18].

However, there is still a long way to go in order to properly implement these practices on a much wider scale. Knowledge with regards to sustainable production field is fragmented 


\section{International Journal of Engineering Applied Sciences and Technology, 2021 \\ Vol. 6, Issue 2, ISSN No. 2455-2143, Pages 62-66 \\ Published Online June 2021 in IJEAST (http://www.ijeast.com)}

however unified theories, typically accepted frameworks and fashions are developing.

\section{CONCLUSIONS}

This paper explores the timeline of Sustainable Manufacturing processes, its implementation through time, how companies can and have implemented it and the challenges in fully implementing such techniques. Climate change and sustainability will fundamentally change manufacturing as each company revisits where plants are located, how materials are sourced and shipped and how tradeoffs in goods are produces. Productivity, efficiency, tracking and visibility will be more important than ever. Various challenges such as efficiency, pricing and need for large scale investing in newer technologies etc. hamper the progress of sustainable manufacturing.

\section{REFERENCES}

[1] Darroch, J. (2017, September 13). What is Sustainable Development and Why Does it Matter? HuffPost. https://www.huffpost.com/entry/what-issustainable-devel_b_11966082

[2] The Fourth Industrial Revolution: what it means and how to respond. (2016, January 14). World Economic Forum.

https://www.weforum.org/agenda/2016/01/thefourth-industrial-revolution-what-it-means-andhow-to-respond/

[3] Companies and sustainable development Insee. (n.d.). Insee.Fr. Retrieved June 15, 2021, from https://www.insee.fr/en/metadonnees/source/serie/s 1227

[4]https://www.cisa.gov/sites/default/files/publications/Versi on_3.0_CISA_Guidance_on_Essential_Critical_Infrastructu re_Workers_1.pdf

[5] Sustainable Manufacturing and Environmental Pollution (SMEP) Programme. (2021). Sustainable Manufacturing and Environmental Pollution (SMEP) Programme. https://www.smepprogramme.org/s/

[6] united nations sustainable. (n.d.). Unctad.Org. https://unctad.org/project/sustainable-

manufacturing-and-environmental-pollution-smep

[7] millennials survey. (n.d.). Msnbc.Com. https://www.msnbc.com/morning-joe/millennialsenvironment-climate-change-msna291876
[8] Malthus, T. (1998). An Essay on the Principle of Population.

Www.Esp.Org. http://www.esp.org/books/malthus/population/malt hus.pdf

[9] Miller, K. (2020, December 8). The Triple Bottom Line: What It Is \& Why It's Important. Business Insights - Blog. https://online.hbs.edu/blog/post/what-is-thetriple-bottom-line

[10] Mineral Supply and Demand into the 21st Century. (2007, January). pubs.usgs.Gov. Retrieved May 10, 2021, from

https://pubs.usgs.gov/circ/2007/1294/reports/paper9.pdf

[11] World on the Edge - Energy Data - Earth Policy Institute. Earth-policy.Org. Retrieved May 10, 2021, from http://www.earth-

policy.org/datacenter/pdf/book_wote_energy_oil.pdf

[12] Sustainable manufacturing: Trends and Research Challenges. (2012). Journal of Trends in the Development of Machinery and Associated Technology.

Published. https://www.tmt.unze.ba/zbornik/TMT2012Journal 101.pdf

[13] Rahimifard, S., Seow, Y., \& Childs, T. (2010). Minimizing Embodied Product Energy to support energy efficient manufacturing. CIRP Annals, 59(1), 2528. doi:10.1016/j.cirp.2010.03.048

[14] billion dollar sustainability. (2016). Theguardian.Com. https://www.theguardian.com/sustainablebusiness/2016/jan/02/billion-dollar-companiessustainability-green-giants-tesla-chipotle-ikea-niketoyota-whole-foods

[15] M. Despeisse , F. Mbaye, P.D. Ball \& A. Levers (2012) The emergence of sustainable manufacturing practices, Production Planning \& Control: The Management of Operations, 23:5, 354-376, DOI: $10.1080 / 09537287.2011 .555425$

[16] Applying lean in Aerospace manufacturing. (2017). Researchgate.Net.

https://www.researchgate.net/publication/32047613 8_Applying_lean_in_aerospace_manufacturing

[17] How 3D printing is revolutionizing manufacturing. (2019, January 4). Hpe.Com. https://www.hpe.com/us/en/insights/articles/how- 
3d-printing-is-revolutionizing-manufacturing1901.html

[18] @inproceedings\{Nambiar2010ChallengesIS, title $=\{$ Challenges in Sustainable Manufacturing $\}$,Author $=\{$ A. N. Nambiar $\}$,year $=\{2010\}\}$

[19] Implementing Lean in aerospace challenging the assumptions and understanding the challenges. (2003, December 1). ScienceDirect. https://www.sciencedirect.com/science/article/abs/p ii/S0166497203000816 